\title{
Veneno Assassino - Desenvolvimento de um Antídoto Universal Contra o Envenenamento por Cobras
}

Vasco Bonifácio
vasco.bonifacio@tecnico.ulisboa.pt $\bullet \bullet \bullet$

O medo e o fascínio pela serpente são ancestrais no Homem. Na mitologia, a serpente representa a sabedoria e a cura, mas também a perfídia e a traição. Nos nossos dias, o ataque por serpentes ainda vitima fatalmente cerca de 140 mil pessoas por ano, tornando-o uma das mais graves doenças neg'ligenciadas. Trata-se de uma emergência clínica documentada em tratados médicos de civilizações tão remotas quanto a do antigo Egito.

A terapia atual consiste na administração de antídotos constituídos por anticorpos derivados de animais hiper-imunizados. A aplicabilidade dos antídotos é limitada à espécie de serpente para o qual foram desenvolvidos, o que, conjuntamente com a alta incidência de reações secundárias anafiláticas, torna a eficiência dos antídotos atuais muito pouco satisfatória. O seu alto-custo e a necessidade de transporte e armazenamento refrigerados diminuem a sua disponibilidade em zonas rurais remotas, onde as serpentes abundam o os ataques ocorrem.

Este projeto visa o desenvolvimento de novos antídotos baseados em compostos químicos de baixa massa molecular, baratos e estáveis à temperatura ambiente, e livres de efeitos secundários anafiláticos. A estratégia passa pelo estudo das toxinas enzimáticas do veneno e pelo desenvolvimento de inibidores que bloqueiem a sua ação. Pretende-se assim obter um antídoto barato e fácil de armazenar fora de contexto hospitalar, que retarde/bloqueie a ação das toxinas, permitindo à vítima chegar a um hospital em segurança e sem consequências irreversíveis.
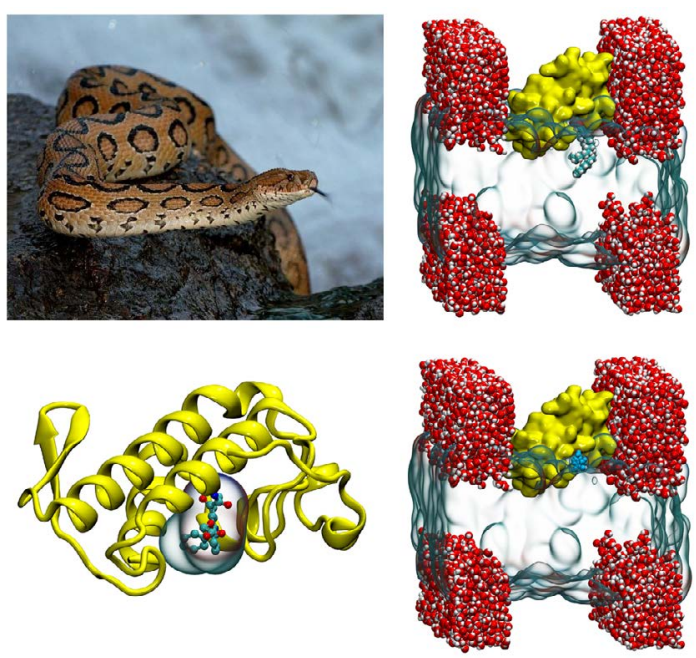

0 veneno da víbora de Russell (topo esq.) é composto por dezenas de toxinas, entre as quais a fosfolipase $\mathrm{A} 2$, altamente miotóxica por hidrolisar a membrana de miócitos (topo dir.). Inibidores como o varespladib ligam-se ao centro ativo da enzima (base esq.) impedindo-a de realizar a sua ação miotóxica (base dir.).

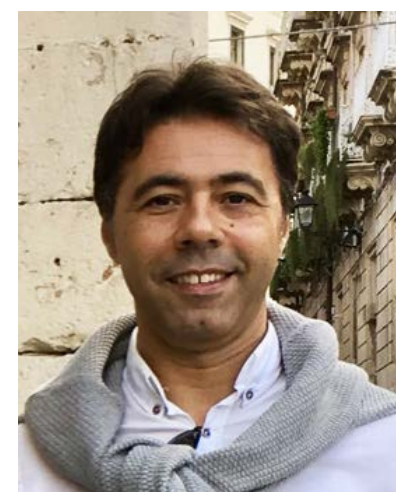

Ficha Técnica do projeto

Pedro A. Fernandes

Referência: PTDC/QUI-OUT/1401/2020.

Financiamento: FCT (Portugal), 2021-2024.

Equipa: FCUP-U. Porto - Pedro A. Fernandes (IR), Maria J. Ramos (co-IR), Ana Luísa Oliveira. Colaboradores - Saulo da Silva (U. Cuenca, Equador), Andreimar Soares (Fundação Fiocruz, Rondônia, Brasil), José-Maria Gutierrez (Instituto Clodomiro Picado, Costa Rica), Ashis Mukherjee (U. Tezpur, India e U. Boulder, Colorado, EUA). 